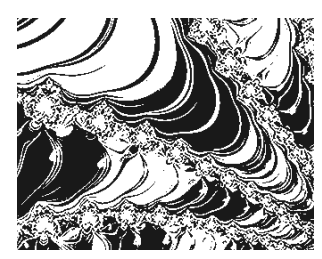

https://doi.org/10.5559/di.29.4.04

"PEDAGOGIJA SLUŠANJA" VS. "PEDAGOGIJA SLUŠANJA ODGOJITELJA": ETNOGRAFSKO ISTRAŽIVANJE O AUTONOMIJI DJETETA U VRTIĆIMA U CRNOJ GORI

Jovana MAROJEVIĆ, Katarina TODOROVIĆ, Saša MILIĆ Sveučilište Crne Gore, Filozofski fakultet, Nikšić, Crna Gora

UDK: $373.24(497.16): 39$

373.24(497.16):165

Izvorni znanstveni rad

Primljeno: 16. 10. 2019.

$U$ radu se razmatra fenomen autonomije djeteta iz motrišta osobnih epistemologija odgojitelja i odnosa moći u relacijama odrasli : dijete u praksama institucionalnog odgoja u Crnoj Gori. Konstruktu autonomije djeteta pristupa se sa stajališta kritičko-konstruktivističke teorije i teorije o samodeterminaciji kao sociokulturnom produktu oblikovanom etnopedagogijama i osobnim epistemologijama odgojitelja. Osnovni cili etnografske studije provedene $u$ trima predškolskim odgojnim ustanovama u Crnoj Gori bio je istražiti epistemološke teorije odgojitelja analizom praksi institucionalnog odgoja, s obzirom na to da se "način mišljenja o djetinjstvu udružuje s institucionalnim praksama" (Prout i James, 2005, str. 22). Zaključujemo o postojanju objektivističke epistemološke teorije odgojitelja i o dominaciji normativnih odnosa moći $u$ interakcijama odgojiteli : dijete te raspravljamo o posebnom tipu zabiliežene epistemološke "nadmoći". Konstatira se srodnost s rezultatima sličnoga tipa istraživanja u regiii te upućuje na moguću objašnjavajuću vezu kolektivističke kulture te kontrolirajućega motivacijskog stila i autoritarnosti u odgoju.

Ključne riječi: osobne epistemologije odgojitelja, objektivistička epistemologija, odnosi moći, predškolski odgoi

Jovana Marojević, Sveučilište Crne Gore, Filozofski fakultet, Studijski program za pedagogiju, UI. Danila Bojovića bb, 81400 Nikšić, Crna Gora.

E-mail: jovanar@ucg.ac.me 
Autonomija djeteta jest "jedan od najkontroverznijih teorijskih konstrukata u literaturi o razvoju, socijalizaciji i dobrobiti" (Ryan i sur., 2006, str. 795). Za naše razumijevanje autonomije posebno su važne dvije perspektive - kritičko-konstruktivistička, s jedne strane, i perspektiva teorije o samodeterminaciji (SDT), s druge. Autonomiji djeteta u radu se ne pristupa sa stajališta razvojnoga fenomena.

Prema teoriji o samodeterminaciji (Self-Determination Theory), autonomno je ono ponašanje za koje pojedinac ima 1 . unutarnje viđen lokus kauzalnosti; 2 . koje manifestira pravo sopstvo pojedinca koje on osjeća kao potpuno svoje; 3. koje je autentično i u kojem se on osjeća kao "autor", odnosno ono s kojim se osoba poistovjećuje i za koje osjeća odgovornost; 4. koje proizlazi iz volje pojedinca, tj. u skladu je s njegovim vrijednostima i uvjerenjima; 5 . koje podrazumijeva djelovanje (agency) biti autonoman znači ponašati se kao agens, kao učinkovit $i$ iskusiti osjećaj "izbora" i voljnosti u tim akcijama (Ryan i sur., 2006).

Za razumijevanje autonomije $u$ obrazovnom kontekstu od posebne je važnosti motivacijski stil odgojitelja. On može varirati na kontinuumu od kontrolirajućega stila do stila koji podržava autonomiju, uključujući i neutralni, odnosno onaj stil koji predstavlja kombinaciju prvih dvaju (Deci i sur., 1981). Motivacijski stil podrazumijeva "orijentaciju nastavnika ka kontroliranju vs. autonomiji" i ima određeni obrazac koji traje (Reeve, 2016, str. 130). Rezultati velikoga broja studija (Ryan i sur., 2006; Ryan i Deci, 2000; Deci i Ryan, 1995; Stefanou i sur., 2004; Jang i sur., 2010) govore u prilog tomu da "stil podučavanja ima ključnu ulogu u definiranju praksi koje podržavaju autonomiju", neovisno o djetetovoj dobi (Koivula i sur., 2017, str. 2).

Sažimljući rezultate velikoga broja istraživanja koja su proveli utemeljivači SDT-a (Reeve i Jang, 2006; Reeve i sur., 2004; Jang i sur., 2010; Reeve i sur., 2014; Reeve, 2016), kao i rezultate nekih srodnih istraživanja o autonomiji djece i motivacijskom stilu odgojitelja u vrtiću (Koivula i sur., 2017), dajemo pregled osnovnih kontekstualnih i interpersonalnih karakteristika motivacijskoga stila koji potiče autonomiju i kontrolirajućega motivacijskog stila.

Razvoju autonomije u djece dominantno pridonose sljedeće kontekstualne i interpersonalne karakteristike:

- omogućavanje izbora djetetu

- prihvaćanje i poštovanje te pokazivanje zainteresiranosti za djetetove osjećaje, mišljenja i stajališta

- upotreba informacijskoga jezika

- njegovanje djetetove unutarnje motivacije 
DRUŠ. ISTRAŽ. ZAGREB GOD. 29 (2020), BR. 4, STR. 575-597

MAROJEVIĆ, J. I SUR.: "PEDAGOGIJA SLUŠANJA"..
- ohrabrivanje samoinicijative

- uključenost odraslih

- responzivnost odraslih

- $\quad$ osiguravanje odgovarajuće strukture okruženja

- potpora emocionalnoj regulaciji i sl.

Razvoj djetetove autonomije dominantno opstruiraju sljedeće kontekstualne i interpersonalne karakteristike:

- materijalno nagrađivanje ponašanja

- $\quad$ primoravajuće/nasilne motivacijske tehnike - manipulacija nagradama, prijetnja kaznama

- jezik kontrole/direktivnost

- $\quad$ pritisak da se misli/osjeća na određen način

- upotreba dominantno vanjskih izvora motivacije

- odsutnost mogućnosti izbora

- $\quad$ odsutnost emocionalne topline i responzivnosti u odnosu na dijete

- $\quad$ kontroliranje

- evaluacije, ocjenjivanja i sl.

Iako se autonomija najčešće dovodi u vezu s mogućnosti izbora (Stefanou i sur., 2004), taj se djetetov izbor najčešće odnosi na organizaciju (dogovaranje pravila rada, vremena trajanja ili vremena završetka aktivnosti, tempa rada i sl.) ili proceduru (slobodu izbora medija, materijala, ideja na kojima će se raditi i sl.) neke aktivnosti ili zadatka. No organizacijski ili proceduralni izbori jesu nužni, premda ne i dovoljni, uvjeti za djetetovo duboko angažiranje u zadatku, odnosno učenju - to je moguće jedino ako je na djelu i kognitioni izbor, odnosno kognitiona autonomija djeteta, koja podrazumijeva vlasništvo nad samim učenjem (Stefanou i sur., 2004).

Suvremeno shvaćanje djetetova procesa učenja ne može se konceptualizirati bez autonomije djeteta (osobito kognitivne) kao njegove okosnice. Pristupajući učenju sa socio-konstruktivističkoga (L. S. Vigotski) i kritičko-konstruktivističkoga (P. Freire, A. Giroux, P. McLaren, J. Habermas, G., MacNaughton) stajališta, učenje se shvaća kao osobna kreacija i konstrukcija nositelja toga procesa, $u$ dijalogu s odraslim u procesu intersubjektivne razmjene, odnosno "dijeljenja iskustvenog sadržaja (...) između više subjekata" (Zlatev, 2008, str. 1). Bilo da govorimo o scaffoldingu ili sukonstrukciji, $u$ temelju tih praksi učenja stoje zajedničko rješavanje problema, intersubjektivnost, osiguravanje da dijete bude stalno $u$ "zoni narednog razvoja", toplina i responzivnost te promocija samoregulacije (Berk i Winsler, 1995), kao i ostvarivanje "neprekidnoga zajedničkog mišljenja", koje podrazumijeva svijest odgojitelja o djetetovu razumijevanju ili sposobnosti i odgovaranje na nju, 
DRUŠ. ISTRAŽ. ZAGREB GOD. 29 (2020), BR. 4, STR. 575-597

MAROJEVIĆ, J. I SUR.: "PEDAGOGIJA SLUŠANJA"... i aktivnu sukonstrukciju ideje ili vještine (Siraj-Blatchford i sur., 2002, str. 49). Neprekidno zajedničko mišljenje predstavlja "učinkovitu pedagošku interakciju u kojoj dva ili više pojedinaca rade $u$ intelektualnom smislu zajednički na rješavanju nekoga problema, razjašnjavanju nekoga koncepta, procjeni neke aktivnosti ili proširivanju neke teme" (Siraj-Blatchford i Manni, 2008, str. 7) te stoji u temelju razvoja metakognitivnih znanja i ključna je odlika najučinkovitijih konteksta predškolskog odgoja i obrazovanja (Siraj-Blatchford i sur., 2002). Taj se kontekst, pak, ne može ostvariti bez primjene strategija za razumijevanje značenja što ih dijete pripisuje "predmetu" učenja te stvaranja i proširivanja zajedničkoga značenja, kao što su postavljanje pitanja i davanje objašnjenja, koji zapravo stoje u osnovi učinkovite sukonstrukcije (Jordan, 2004; Zurek i sur., 2014; Siraj-Blatchford i sur., 2002). Mnoge studije pokazale su da u predškolskom odgoju često dominiraju pitanja odgojitelja koja su zatvorenoga tipa, a ona kontroliraju i suzuju moguća polja djetetovih značenja ili objašnjenja (Dickinson i Caswell, 2007; Siraj-Blatchfors i Manni, 2008; Gjems, 2011; Siraj-Blatchford i sur., 2002), pa se sukonstrukcija objašnjenja zapravo rijetko događa u vrtićima (Peterson i French, 2008; Siraj-Blatchford i Manni, 2008).

Dakle, ako se zaista želi ostvariti što šire polje intersubjektivnosti kako bi učenje zaista postalo "rekognicija", odnosno "spoznavanje nečega nanovo", obogaćeno znanjima i značenjima drugih (Rinaldi, 2006, str. 102), a što pretpostavlja djetetovu autonomiju u procesu učenja - mora doći do svojevrsnog obrata u odnosima moći u interakcijama odrasli : dijete koje počivaju na deficitarnim modelima djetinjstva i dominaciji razvojnopsihološkoga diskursa (MacNaughton, 2000). Osnovna je premisa da djeca grade značenja "u situacijama u kojima su odnosi moći već uspostavljeni i u kojima se suprotstavljena značenja bore za moć" (MacNaughton, 2004, str. 51); djeca ne mogu stvarati značenja koja ona hoće, jer su ograničena i konstruirana $u$ odnosu na već postojeću dinamiku moći (MacNaughton, 2003, 2004).

Postmoderna pedagogija, meklarenovski revolucionarna, mora biti utemeljena na učeničkom i nastavničkom propitkivanju i pregovaranju znanja i identiteta, i to legitimiranjem vlastitih autoriteta (Giroux, 1999; Kincheloe, 2008; Aronowitz i Giroux, 1997; Shor, 1993; Meklaren, 2013), čime se osigurava "epistemološko osvještavanje" samih učenika (Freire, 1996, 2001, 2017; Shor, 1993; Hinchey, 2004; Kincheloe, 2008). Da pedagogija ne bi postala sredstvom "kolonizacije" svijeta života (Habermas, 1987), nužno je proces učenja razumjeti kao deliberationu praksu (Marojević i Milić, 2017).

Osnovni preduvjet takva epistemološkog "obrata" - kretanja od objektivističke (Roth i Weinstock, 2013) ili FIDUROD 
DRUŠ. ISTRAŽ. ZAGREB GOD. 29 (2020), BR. 4, STR. 575-597

MAROJEVIĆ, J. I SUR.: "PEDAGOGIJA SLUŠANJA".
(Kincheloe, 2008) epistemologije prema relativističkoj (Roth i Weinstock, 2013) - svakako je osnaživanje djetetove autonomije. Istraživanja su pokazala da je poučavanje koje podržava autonomiju moguće predvidjeti relativističkom epistemološkom teorijom nastaunika (Roth i Weinstock, 2013).

\section{CILJ ISTRAŽIVANJA}

Osnovna je opća pretpostavka našega istraživanja ${ }^{1}$ da se "način mišljenja o djetinjstvu udružuje s institucionalnim praksama" (Prout i James, 2005, str. 22), prenoseći određene načine mišljenja i osjećaja na sudionike tih praksi. Osnovni cilj studije bio je istražiti epistemološke teorije odgojitelja analizom institucionalnih praksi odgajanja, a interakcijama odgojitelj : dijete u strukturiranim aktivnostima učenja. Naše ključno istraživačko pitanje bilo je: koji i kakav diskurs djetinjstva stoji u temelju institucionalnoga predškolskog odgoja u promatranim sredinama.

\section{METODE}

\section{Valjanost studije}

Valjanost naše studije (Carspecken, 1996) temelji se na:

- Vanjskoj valjanosti, koju osiguravamo multiperspektivnošću studije (Wiersma, 1991; Goodwin i Goodwin, 1996)

\footnotetext{
${ }^{1}$ Istraživanje je provedeno kao dio doktorske disertacije "Autonomija dieteta $\mathrm{i}$ institucionalni model djetinjstva u Crnoi Gori".
}

Osnovna istraživačka pitanja kojima smo se rukovodili bila su: Koje su osobne epistemologije odgojitelja? Kako odgojitelji pristupaju znanju i kako organiziraju učenje djece? Kakvi su odnosi moći u interakcijama odgojitelj : dijete? Na čemu odgojitelj temelji svoj autoritet te kolidira li autoritet odgojitelja s autonomijom djeteta i sl.?

Istraživanje se oslanja na interpretationu, fenomenološku, kritičku te poststrukturalističku istraživačku paradigmu, karakterističnu za nove studije djetinjstva, te na nove paradigme ranog i predškolskog odgoja i obrazovanja, jer omogućuju dekonstrukciju finih slojeva značenja "teksta" (MacNoughton, 2005).

Istraživanje je koncipirano kao kritička etnografija (Schwandt, 2007; Hymes, 2004; MacNaughton, 2005; Aubrey i sur., 2005; Carspecken, 1996; Freeman i Mathison, 2009; Leibzig i Leach, 2001; Pole i Morrison, 2003; Wiersma, 1991; Lincoln i Guba, 1985; Goodwin i Goodwin, 1996), s elementima fukoovske analize diskursa (Parker, 1992), a sve s ciljem pronalaženja dominantnih diskursa u modelu djetinjstva odgojitelja obuhvaćenih uzorkom. - istraživanje smo proveli u trima sredinama, pa nam srodnost među rezultatima istraživanja osigurava valjanost studije.

- Unutarnjoj valjanosti (Wiersma, 1991; Goodwin i Goodwin, 1996), koja se osigurava vremenom provedenim $u$ 
DRUŠ. ISTRAŽ. ZAGREB GOD. 29 (2020), BR. 4, STR. 575-597

MAROJEVIĆ, J. I SUR.: "PEDAGOGIJA SLUŠANJA".. istraživačkim sredinama (Goetz i LeCompte, 1984) kako bi se osiguralo da interpretacija podataka iskazuje iskustva subjekata u istraživanju (Robinson, 1994), kao i triangulacijom. Slijedili smo pravilo "produženog uključivanja" (Carspecken, 1996, str. 88), kako bi se smanjio tzv. Hotornov efekt; po dva istraživačka dana provedena su $u$ istraživanim sredinama kako bi se istraživač i subjekti istraživanja naviknuli jedni na druge - djeca su se upoznala s načinom rada kamere, snimala su jedna drugu i slično (videomaterijali snimljeni u dva "probna" dana istraživanja nisu uključeni u transkript za analizu);

- $\quad$ "Fokusiranim uključivanjem" isključivo u interakcije odgojitelja i djece osigurali smo dubinu pristupa (Lincoln i Guba, 1985).

- Triangulaciju smo postigli služeći se (Hammersley i Atkinson, 2007; Hymes, 2004; Aubrey i sur., 2005; Carspecken, 1996; Freeman i Mathison, 2009; Pole i Morrison, 2003; Murchison, 2010; Robinson, 1994) sljedećim:

- $\quad$ sudjelujućim promatranjem, uz snimanje videokamerom (Erickson i Wilson, 1982)

- $\quad$ vođenjem "terenskih zabilješki", koje su prema mnogim metodolozima u najboljem suglasju s videosnimanjem kao metodom (Carspecken, 1996; Robinson, 1994; Erickson i Wilson, 1982)

- $\quad$ primjenom Protokola promatranja dnevnih aktivnosti kao dodatnoga istraživačkog instrumenta.

- Kad god je bilo potrebno (osobito pri kodiranju i interpretaciji), pribjegavali smo postupku zajedničkog razmatranja i analiziranja sa suradnicima istraživačima (engl. peer-debrifing) (Carspecken, 1996, str. 89), kako bismo povećali objektivnost, odnosno smanjili mogućnost neutemeljena kodiranja ili interpretacije podataka, neutemeljenih zaključaka, potkradanja preferencija i slično.

\section{Istraživački kontekst}

Istraživanje smo obavili u predškolskim odgojnim grupama koje uglavnom čine petogodišnjaci i šestogodišnjaci, prije svega kako bismo izbjegli moguću implikaciju razvojnopedagoške misli o autonomiji kao najvažnijoj potrebi djeteta $u$ dobi od dvije i tri godine (Erikson, 2008), kao i zbog činjenice da djeca te dobi imaju razvijenije sposobnosti pregovaranja i participacije $u$ usporedbi s djecom svih drugih dobi obuhvaćenom predškolskim odgojem i obrazovanjem (Vranješević, 2012), što nam je bilo važno zbog mogućeg problematiziranja pitanja odnosa moći u interakcijama odgojitelj : dijete.

Istraživanje je provedeno od veljače do lipnja 2017. godine. Bile su obuhvaćene tri vrtićke sredine iz tri grada u raznim 
DRUŠ. ISTRAŽ. ZAGREB GOD. 29 (2020), BR. 4, STR. 575-597

MAROJEVIĆ, J. I SUR.: "PEDAGOGIJA SLUŠANJA"..

regijama Crne Gore, bez primarne namjere komparativne analize među njima, nego zbog osiguravanja multiperspektivnosti studije.

U istraživanju smo proveli 24 istraživačka dana, od kojih je za analizu izabrano 15, u svakoj istraživačkoj sredini po pet. Ukupno trajanje videomaterijala, koji je osnova naše analize, prikazano je u Tablici 1 ( $u$ satima i minutama).

\begin{tabular}{lcrrrrrr}
\hline Grad & Dan I. & II. & III. & IV. & V. & Vrijeme \\
\hline Herceg Novi & $210 \mathrm{~min}$ & $294 \mathrm{~min}$ & $285 \mathrm{~min}$ & $278 \mathrm{~min}$ & $291 \mathrm{~min}$ & $22 \mathrm{~h} 38 \mathrm{~min}$ \\
Nikšić & $236 \mathrm{~min}$ & $245 \mathrm{~min}$ & $293 \mathrm{~min}$ & $270 \mathrm{~min}$ & $221 \mathrm{~min}$ & $21 \mathrm{~h} 5 \mathrm{~min}$ \\
Podgorica & $263 \mathrm{~min}$ & $289 \mathrm{~min}$ & $267 \mathrm{~min}$ & $274 \mathrm{~min}$ & $211 \mathrm{~min}$ & $21 \mathrm{~h} 44 \mathrm{~min}$ \\
Ukupno & & & & & & $15 \mathrm{dana}$ & $65 \mathrm{~h} 27 \mathrm{~min}$
\end{tabular}

(1) TABLICA 1

Prikaz vremenskog rasporeda istraživanja

$\rightarrow$ TABLICA 2 Subjekti u istraživanju
Subjekte u našem istraživanju činilo je ukupno 6 odgojitelja i 68 djece tijekom cijelog istraživanja. Istraživačke grupe bile su relativno ujednačene prema broju djece i broju odgojitelja (po dvije odgojiteljice u svakoj istraživačkoj sredini).

\begin{tabular}{|c|c|c|c|}
\hline \multirow[b]{2}{*}{ Grad } & \multicolumn{3}{|c|}{ Odgojiteljice } \\
\hline & Stručna sprema & $\begin{array}{r}\text { Godine } \\
\text { radnoga staža }\end{array}$ & Djeca (po danu) \\
\hline \multirow[t]{2}{*}{ Herceg Novi } & V1 - Visoka & 22 & $\min .13-\max .23$ \\
\hline & $\mathrm{V} 2-\mathrm{BA}$ & 11 & \\
\hline \multirow[t]{2}{*}{ Nikšić } & V1 - Viša & 25 & $\min .17-\max .25$ \\
\hline & V2 - Visoka & 16 & \\
\hline \multirow[t]{2}{*}{ Podgorica } & $\mathrm{V} 1-\mathrm{BA}$ & 7 & $\min .12-\max .20$ \\
\hline & V2 - Visoka & 17 & \\
\hline Ukupno & 6 & & 68 \\
\hline
\end{tabular}

Aktivnosti smo snimali ručnom videokamerom s dovoljno male udaljenosti da zabilježimo što više verbalnih interakcija, ali i s dovoljno velike udaljenosti da ne budemo doživljeni kao ometajući čimbenik tijekom same aktivnosti (2 do 3 koraka od odgojiteljice).

\section{Etička pitanja studije}

Pristanak subjekata u istraživanju (djece i odgojitelja), odnosno potpisanu suglasnost za istraživanje (Hammersley i Atkinson, 2007; Pole i Morrison, 2003), osigurali smo tako što smo za istraživanje dobili Odobrenje Zavoda za školstvo i Ministarstva prosvjete te suglasnost ravnatelja, stručne službe i odgojitelja za istraživanje u trima odgojnim grupama. Svaki pojedini odgojitelj dao je svoju suglasnost za sudjelovanje $u$ istraživanju. Odgojitelji su bili upoznati s temom, ciljem i na- 
DRUŠ. ISTRAŽ. ZAGREB GOD. 29 (2020), BR. 4, STR. 575-597

MAROJEVIĆ, J. I SUR.: "PEDAGOGIJA SLUŠANJA"... činom istraživanja, čime se zadovoljava etički imperativ odsutnosti obmanjivanja (Viling, 2016).

Sudjelovanje djece $u$ istraživanju omogućeno je pod okriljem već postojećih Odluka predškolskih ustanova uz suglasnost roditelja za sudjelovanje $u$ istraživanjima $u$ znanstvenoistraživačke svrhe. Odgojiteljima je dana mogućnost da $\mathrm{u}$ bilo kojem trenutku prekinu istraživanje.

Privatnost subjekata $u$ istraživanju (Hammersley i Atkinson, 2007; Pole i Morrison, 2003) štiti se stavljanjem inicijala imena za sve izjave koje su dio transkripta.

\section{Kodiranje}

\section{REZULTATI}

Analizom Protokola promatranja dnevnih aktivnosti uočili smo da su aktivnosti u vrtiću većinom vođene i strukturirane, uz primjenu tematskoga planiranja, u kojem odgojitelj obično predstavlja ili uvodi neki koncept koji se poslije razlaže na niz aktivnosti u tzv. interesnim centrima. Organizacija je takva da su materijali već pripremljeni i ponuđeni, pa je nedvosmisleno kako ih upotrijebiti. Kad je riječ o slobodnim aktivnostima, one $u$ pravilu slijede nakon što je prvotni segment "vođenih" ili strukturiranih aktivnosti završen. Djeca se tada samoorganiziraju u neke od sljedećih aktivnosti: crtanje, igranje društvenih igara, igranje uloga u centru za dramatizaciju ili najčešće, najduže i najobuhvatnije - igranje igre uloga. Ovdje je gotovo uvijek riječ o aktivnostima u kojima odgojitelj ne sudjeluje ni na koji način. 


\section{"Slušaj i pamti" pedagogija}

U svim odgojno-obrazovnim grupama u kojima smo bili odgojitelji često se pokazuje praksa "obnavljanja" znanja - "već smo to znali", ali "se prisjećamo" (EP2 HN4 ), "to smo prešli" i slično (EP2 HN26). Ono što je upitno jest da djeca koja nisu bila prisutna u vrtiću nekoga ranijeg dana kad se to "znanje učilo/usvajalo" ne mogu to znati:

V1: Što smo rekli, kakva može biti voda? ... Što smo rekli? ... Jučer smo govorili ... Para, jest, voda može biti para ... Kakva još može biti? ...

A.: Da se baci para unutra i da zamisliš želju ...

V1: Ne, ti A. nisi jučer bio tu ... Ne para kao novac nego para kao dim, magla.

EP2 PG3 27-29

Svoju dominaciju u pogledu iznošenja znanja odgojitelji u svim odgojnim grupama posebno pokazuju nekom vrstom strategije "slušaj i pamti" (EP3): "ti ne slušaš, zato i ne znaš" (EP3 PG5 12), ili gotovo identično "ne slušaš, pa zato i ne znaš" (EP3 NK4 74), odnosno "svi super radite, samo da slušate zadatak" (EP3 NK4 78). Posebno eksplicitno odnos slušanja i znanja iskazuje jedna odgojiteljica u nikšićkom vrtiću: "Da biste znali ... morate biti jako poslušni ... da čujete što ćemo vam objasniti, jeste čuli" (EP3 NK2 34), uz implicitnu poruku da je poslušan/dobar onaj koji sluša, a jedino ako sluša, može $i$ znati.

U svakoj od sredina u kojima smo boravili prisutan je i rječnik koji upućuje na specifično epistemološko opredjeljenje odgojitelja - strukturirane aktivnosti učenja uglavnom su koncipirane tako da imaju za cilj vrlo određen materijalni ishod, odnosno "proizvod". Stječe se dojam da se znanje i učenje jednostrano doživljavaju kao proizvođenje, o čemu svjedoči i jedan pomalo mehanicistički i tehnicistički jezik odgojitelja (EP4) - "odraditi zadatak" (NH1 114, HN2 22), "dovršiti rad", "još da to završimo" (HN4 58, 59) i slično.

$S$ tim u vezi, u govoru i ponašanju odgojitelja prenosi se dojam dekontekstualiziranosti znanja ili zadatka, ili, na koncu, samoga proizvoda - točnije, instrukcije za rad i objašnjenja koja se daju na početku ne smještaju aktivnost koju djeca izvode u kontekst nekoga šireg fenomena, procesa, pojma, teme kojom su se bavili toga dana ili toga tjedna, nego ih, naprotiv, ogoljuju i lišavaju smisla te svode na niz manualnih radnji - sjeckaj, sijeci, lijepi, boji, crtaj, oblikuj, umijesi (EP8).

V1: Vi trebate ovo izrezati ... ali morate biti precizni, vrijedi? ...

(...)

V1: A vi ćete, sad ću vam dati listove da obojite u plavo, ali nemojte da vam bude previše mokro, umočite u boju, onda osušite, vrijedi? ...

(...)

(Djeca je pitaju što trebaju raditi.)

V1: Ništa, samo mi trebate obojiti tu površinu. 
DRUŠ. ISTRAŽ. ZAGREB GOD. 29 (2020), BR. 4, STR. 575-597

MAROJEVIĆ, J. I SUR.: "PEDAGOGIJA SLUŠANJA"...
U takvu kontekstu događa se da odgojitelj jednostavno instruira djecu za mehaničko obavljanje zadatka. Djeca vrlo često ne razumiju svrhu svoje aktivnosti, ona im je nametnuta izvana, o čemu najbolje svjedoči primjer djeteta koje se i ne sjeća svoje jučerašnje aktivnosti "proizvođenja" vjetrenjače jer je vjerojatno bila jednako mehanizirana.

V1: Igrat ćemo se sutra toga, danas ćemo samo prošetati i postaviti ove vjetrenjače koje smo napravili ...

D.: A što su vjetrenjače?

V1: Oni vrtuljci koje smo jučer pravili ... Da ih stavimo u zemlju, pa da ih vjetar pokreće...

PG3 224-226

Savršeno komplementaran element takve epistemologije jest doživljaj aktivnosti učenja kao konačnoga, dovršivog procesa (EP5). Utjelovljen je u dominaciji sintagmi poput "nisi još završio", "nisi ni do pola", "nemoj da ostaju praznine", "još moraš malo" te pojavljivanju odgojitelja u ulozi evaluatora je li aktivnost dovršena ili nije, uz sintagme poput "da vidim"; "Sjedi, sjedi, nisi još završio", "Nemoj da nam ostaju praznine, da se malo potrudite", "Nisi to završio", "'Ajde L., nisi ni do pola stigao" (HNI 127-134). Ta vrsta vanjske evaluacije ponovno svjedoči o opstruiranju djetetove samoevaluacije kao autonomnoga procesa. Aktivnost "učenja" jest težnja k vrlo određenom cilju, nikako trajanje $u$ procesu, razgovaranje o poteškoćama, a osobito ne planiranje zajedno s djecom.

\section{Pitanja za "provjeru" znanja}

Dominiraju pitanja reproduktivnoga karaktera, a vrlo rijetko objašnjavajuća. Najveća koncentracija pitanja događa se u pravilu nakon uvodnoga, najčešće frontalnog, dijela organizacije dana, i to najčešće nakon čitanja neke priče; ona su gotovo isključivo reproduktivnoga karaktera - od djece se traži da se prisjete, odnosno reproduciraju, fabulu priče, dio po dio, isključivo na pitanja odgojitelja tko, što, kada, gdje (ne i kako ili zašto, sic!).

V1: Recite mi gdje raste šumska jagoda?

(...)

V1: Ne, ona sama raste $i$ zato je jako zdrava. Kakve je boje jagodica?

(...)

V1: A kakve je boje peteljčica?

(...)

V1: A tko je prvi ugledao jagodu?

(...)

V1: A tko je proi čuo komarca?

(...)

V1: Sto je žaba učinila? 


\section{Instruktivnost odgojitelja}

Kad je riječ o strukturiranim aktivnostima učenja, odgojiteljice pokazuju veliku instruktivnost. Nije riječ samo o općim, uvodnim instrukcijama kako neki zadatak treba izvesti nego o previše striktnim uputama $u$ pojedinim segmentima obavljanja zadatka, za čije uspješno obavljanje sasvim sigurno nije potrebna takva preciznost $\mathrm{u}$ izvođenju. U cijelom tom procesu odgojiteljice upotrebljavaju mnogo glagola $u$ imperativu. Odgojiteljice inzistiraju na tome da djeca najprije saslušaju sve njihove upute, pa i kad su zadaci samorazumljivi.

V1: Evo gledaj ovamo što radimo ... S., sad se radi ... Napravit ćemo malu kuglicu ... E ovako ... Polako, pazite da se ne nabodete ... Moramo dobro pritisnuti ... Jeste vidjeli kako? ...

Djeca: $D a$.

V1: E ovako, malu kuglicu napravite, polako ... Lagano pritisnemo, okrenemo coijet i prstićima ... Evo vidiš ...

EPI 17-19

V2: Uzmite, evo vidi ovako, tko želi, pa ćemo popunjavati ... (Uzima čašicu sa sjemenkama i prosipa ih prstima po travi.) Tko želi to? ... Evo može i ovo. (Uzima čašicu s drugim sjemenkama.) Fino popunite ... To sad možeš ovdje sipati ... (Neko dijete sipa, ona instruira.) E sad ti tu travicu stavi gdje misliš ... Ali ovako uzmi ručicama ... Ne, ne, polako ... (Rukom sugerira V. da stane.)

IN1 NH2 58

U okviru strukturiranih aktivnosti, ali i u slobodnim aktivnostima djece, prisutna je i instruktivnost odgojitelja u pogledu mjesta izvođenja aktivnosti - i to takva koja sugerira da je stol poželjno mjesto za igru u situaciji u kojoj on to nije igranje sitnim životinjama na stolu (IN2).

V2: T., donesite te igračke ovamo za stol, $i$ oni se hoće igrati ...

A.: $S$ djevojčicama se želim igrati ...

V2: Ne možete se tu igrati, 'ajmo za stol ... Nema tu, ne po podu i ne znam ni ja, po kutcima, za stol sjednite ...

IN2 PG5 140-142

\section{"Pedagogija za stolom"}

Osim neposrednog "upravljanja" djetetovim tijelom, prisutne su i određene prakse koje uključuju fizičko ograničavanje djetetova kretanja u prostoru. Postoje, naime, određeni toponimi $\mathrm{u}$ učionici na koje se vrlo često i vrlo neutemeljeno svodi, odnosno u koje se smješta, aktivnost djece - "za stolom", "uz ormar", "na tepihu". U podgoričkom je vrtiću vrlo naglašeno inzistiranje odgojiteljica da djeca sjede za stolom, bilo da su u strukturiranoj aktivnosti učenja, slobodnoj igri, čekanju, tranziciji između dviju aktivnosti i slično.

V2: E, jesmo li gotovi? ... Ajmo onda složite tanjure i djevojčice idu u kupaonicu ...

V2: Dječaci, ostanite za stolom, nisam rekla da ustajete ... 
DRUŠ. ISTRAŽ. ZAGREB GOD. 29 (2020), BR. 4, STR. 575-597

MAROJEVIĆ, J. I SUR.: "PEDAGOGIJA SLUŠANJA"...
V2: M., za stol sjednite, M. ... (Oni ustaju, šetaju ...)

V2: Ajde, uzmite stolice $i$ sjednite tamo ...

V2: V. sjedni ovdje ... B., sjedni ovdje ... (A. se kreće ... prima ga za rame ...) Ja kažem sjedni ovdje ... (Povisi ton, viče.) Kad kažem sjedni, onda sjedni. Zar vi ne čujete što ja govorim, je li? V., sjedni ovdje. (V. nosi dvije stolice.) Dovoljno je stolica, sjedni ovdje. Ja ne znam komu govorim. M., sjedni M. na stolicu.

(M. je otišao do kupaonice.)

(Ide pogledati djevojčice u kupaonici V2. Vraća se do dječaka. V. stoji pokraj stolice. Stavlja mu ruku na rame i govori ...)

V2: Sjedni dolje.

V2: Izvoli M., sjednite na svoja mjesta ... V. ..., sidi N., 'ajde izbroj djecu $N$. E da vidimo sad malo djevojčice da se razmjestite, da mi ne pričate ... (Uzima ih za ruku, namješta ih kamo da sjednu ...)

FA3 PG4 41-54

U ekstremnoj situaciji, dok oko osam i pol minuta odgojiteljice V1 i V2 traže neki zagubljeni papir, petnaest puta (sic!) od djece traže da sjednu za stol, bez ikakva drugog prijedloga ili reakcije.

\section{"Pedagogija slušanja odgojitelja" - odnosi moći u interakciji odgojiteli : dijete}

U sve tri promatrane sredine svi odgojitelji često implicitno ili eksplicitno rukovode ponašanjem $u$ interakciji ili ishodom interakcije na temelju svoje socijalne pozicije ili statusa nadređenog, a koji zauzvrat zbog kulturnih normi određuje poziciju njemu podređenoga (djeteta). U svim situacijama normativne moći (OM1) zatječe se manje ili više eksplicitno pozivanje na vlastiti status: "dok učiteljica objašnjava, ne možete me prekidati" (OM1 NK4 43), "treba li učitelja slušati" (OM1 NKI 38), "Nina, ustani, sad ste svi vidjeli jedni od drugih, e ne može tako, naljutit će se učiteljica" (OM1 NK1 40), "Tu sjedi N. gdje sam ti ja stavila" (OM1 PG3 142), "E vidite kakav je stol, ja ovo ne želim ovako" (OM1 NK3 92-95), "Ja sam nešto rekla ... N." (OM1 HN5 13), "N., jesam li ja rekla da to radiš?" (OM1 PG3 20), "E, to ne želim, učiteljica takve stvari ne želi vidjeti jer to nije lijepo ..." (OM1 NK1 56), "V1: Ja sam nešto rekla, svatko radi svoj zadatak" (OM1 NK4 53), "Zašto mi slagalice ne pokupite?" (OM1 PG1 219), "N., jesam li rekla da to radiš?" (OM1 PG3 20).

Osim toga, postoje situacije u kojima djeca pitaju odgojitelja za neku vrstu dozvole i koje su nam, bez obzira na odgojiteljev odgovor, pokazatelj određenih ustanovljenih odnosa moći u kojima djeca točno znaju što je " $u$ njihovoj nadležnosti", a što nije - pa makar to bilo (sic!) uzimanje bojica ili društvene igre s police (OM2), za bojenje flomasterima, za igru, ili da naprave kućicu (kao dio igre) i sl.

Odgojitelj se, u pravilu u situacijama "vođenih", strukturiranih aktivnosti učenja javlja i kao neka vrsta evaluatora, 
DRUŠ. ISTRAŽ. ZAGREB GOD. 29 (2020), BR. 4, STR. 575-597

MAROJEVIĆ, J. I SUR.: "PEDAGOGIJA SLUŠANJA".. čime se također implicira poruka moći i njegove "završne" riječi u odnosu na učinak, uspjeh, ishod, proizvod na kojem su djeca tijekom aktivnosti radila (OM3).

V1: Sjedi, sjedi, nisi još završio. (...) Nemoj da nam ostaju praznine, da se malo potrudite. (...) Nisi to završio. (...) 'ajde L., nisi ni do pola stigao...

OM3 HNI 128-134

Normativnu moć odgojitelji u podgoričkom vrtiću u nekoliko interakcija pokazuju povišenim tonom (OM4), uz pokazivanje neopravdane nestrpljivosti.

A.: Učiteljice, ovo nije naoštreno ...

V2: (Viče) Oprosti, ovo je pedeseti put da te opominjem ... kad netko govori, što treba raditi A.? ...

A.: Da šutim ...

V2: Pa da pričekaš A., ... Ne mogu vjerovati ... (Nastavlja s M. razgovarati o lavu.)

OM4 PG4 101-104

Interaktivno postignut dogovor, kao još jedan od tipova interakcijske moći, pojavljuje se u značajnom broju situacija koje odlikuje neka vrsta odnosa "usluga za uslugu" ili odnosa "to - ako".

V2: E. M. (odgojiteljica iz druge grupe) povela je svoje đake $u$ šetnju ... Jer su dobri ... A vi ćete ... Vi niste ni učionicu spremili još ...

Netko: Mi smo loši

OM5 PG4 148-152

V1: E, ja sam još nešto htjela učiniti, a sad ne, ne želim, L., ne ponaša se lijepo, ne ponašate se lijepo, P., ne ponašaš se lijepo, F. ... to nije lijepo tako ... Ja sam mislila još po jednu čokoladicu, sad ne, sad razmišljam ... evo sad vidjeti, sad sjedim i gledam ... Da vidimo: P. ništa, Lj., Lj. ništa (djeca se pomalo smiju za stolom, ništa strašno). Da vidimo ... Opasni su kad je u pitanju slatko, svi ... V. dobiva prva čokoladicu, izvoli V., divna si ... D., Š. je jako dobar, D. izvoli ...

Neko dijete: $A$ ja ...

V1: Sad ćemo vidjeti ... Ajde, odlučila sam da svi dobijete čokoladicu, da vidim 'oćete li svi biti dobri i učiteljici to vratiti lijepim ponašanjem ... (dijeli im čokoladice ... P. ide baciti papirić.)

NK3 144-147

Smatramo posebno simptomatičnom poruku (nad)moći koja se djeci šalje visokom instruktivnošću u vođenim aktivnostima. Navest ćemo neke primjere: "Neću na stolu, hoću da sve prstićima radiš ..." (OM8 HN2 39), "Odradit ćete ovako kao farmu" (OM8 HN2 32), "Nisam ... Nije to trava ... Još moraš malo ... Od jedne te da napraviš dvije, tri. 'Ajde isjeckaj ... 'Ajde dobro, možemo ovako staviti ..." (OM8 HN2 64), "Evo gledaj 
DRUŠ. ISTRAŽ. ZAGREB GOD. 29 (2020), BR. 4, STR. 575-597

MAROJEVIĆ, J. I SUR.: "PEDAGOGIJA SLUŠANJA".. vratite se, nisam vam do kraja objasnila i nisam vam dala zadatak koji trebate vi završiti ... sjednite opet ovdje da vas vidim, ne želim tako, e baš ..." (OM8 NK3 69), "V1: Ne možete dok vam ja ne objasnim ... ja sam rekla nešto ... jeste li se smirili ... S., ne možete raditi dok vam učiteljica ne objasni ... F., gledaš li? ..." (OM8 NK4 17).

Pogledamo li shemu svakodnevnih aktivnosti u vrtićima, uočit ćemo obrazac i neku vrstu rutiniziranoga tijeka aktivnosti: uvodne aktivnosti, najčešće čitanje priče ili pjesme, ili razgovor; aktivnosti $\mathrm{u}$ interesnim centrima; slobodne aktivnosti; alternativne i vanjske aktivnosti. Dominantna organizacijska forma učenja odvija se po principu tematskoga planiranja, $u$ okviru interesnih centara, s predominacijom manipulativnih aktivnosti djece. To je upravo onakav pristup organizaciji odgojno-obrazovne prakse u vrtićima za koji Slunjski rabi sintagmu "u okviru" (Slunjski, 2015, str. 187), a koji karakterizira relativno univerzalna metodička shema i precizna vremenska i sadržajna artikulacija.

Pogledamo li naše rezultate o visokom stupnju instruktivnosti odgojitelja, zajedno s predominacijom postavljanja pitanja zatvorenoga tipa u obliku epistemologije "točnog odgovora" - čini se kao da postoje svi uvjeti za djetetovo usvajanje upravo proceduralnih znanja. Visok stupanj instruktivnosti svjedoči o tome da učenje podrazumijeva proces provedbe određenih aktivnosti na točno određen način kako bi se došlo do određenih produkata; odgojitelj najbolje zna na koje će načine dijete shvatiti nešto o nekom fenomenu; dijete nema slobodu izbora načina izvođenja aktivnosti, makar one bile isključivo pitanje vježbanja fine motorike. S druge strane, konceptualna znanja - koja podrazumijevaju razumijevanje principa, uzroka te međusobnih odnosa i slično, kao i metakognitivna znanja - razumijevanje i reguliranje vlastita procesa mišljenja - nisu uopće bila zastupljena. Viši oblici znanja mogu se dosegnuti gotovo isključivo uz pretpostavku epizoda produženoga zajedničkog mišljenja, koje je "neophodan preduvjet najučinkovitijih pedagogija" (Siraj-Blatchford i sur., 2002, str. 49). U promatranim sredinama ni jedna planirana aktivnost učenja nije imala oblik istraživačkog učenja, učenja putem otkrića, učenja putem rješavanja problema, putem izvođenja projekta i slično.

Tipovi aktivnosti i dominantnog angažiranja djece takvi su da u velikoj mjeri "utišavaju" onih "stotinu dječjih jezika" (Malaguzzi, 1998) - načini djetetova izražavanja, načini učenja, istraživanja svijeta, pokazivanja svojih razumijevanja, građenja znanja, uopće načini komunikacije u velikoj su mjeri ograničeni na nevelik izbor simboličkih sredstava ili, točnije, na odgojiteljev izbor simboličkih sredstava. 
DRUŠ. ISTRAŽ. ZAGREB GOD. 29 (2020), BR. 4, STR. 575-597

MAROJEVIĆ, J. I SUR.: "PEDAGOGIJA SLUŠANJA"...
Naime, pogleda li se načelan odnos odgojitelja prema planiranju i strukturi aktivnosti, ponovit ćemo da je riječ o tematskom planiranju kojim rukovodi odgojitelj. Oblici indirektne potpore djetetovu učenju i aktivnosti u vidu scaffoldin$g a$ ili sukonstrukcije nisu dio repertoara pedagoških interakcija odgojitelja (naprotiv, na djelu je visok stupanj instruktivnosti).

Usto, vođene, strukturirane aktivnosti pate od pretjerane šablonizacije, striktnoga načina izvedbe, manjka intelektualnog angažiranja i unutarnje motivacije djece. Ističemo kao posebno važno da se, izuzimajući slobodne aktivnosti, ni jednom $\mathrm{u}$ promatranim sredinama nije dogodilo da ključnu aktivnost potaknu sama djeca, pa čak ni da je potaknu djeca i odrasli u zajedničkoj raspravi.

U kognitivnom smislu, to su aktivnosti koje, iako proizvodne, nisu nužno i kreativne, shvatimo li kreativnost kao nešto što podrazumijeva i invenciju - naime, djeca proizvode, ali ne kreiraju. Metakognitivne sposobnosti djece u pravilu se ne angažiraju jer se djeca ne stavljaju u poziciju da sama planiraju, eksperimentiraju, postavljaju i testiraju pretpostavke, ispravljaju svoje pogreške, donose odluke o tome koji materijal upotrijebiti ili na koji način nešto raditi i slično - jednom riječju, ne stavljaju ih u poziciju da budu intelektualno autonomna.

Mnoga su istraživanja pokazala da se autonomija djece $u$ odgojno-obrazovnom procesu može najneposrednije podržati tako da im se dade sloboda izbora (Stefanou i sur., 2004).

Pogledamo li strukturirane aktivnosti učenja u trima promatranim sredinama, primijetit ćemo da se mogućnosti izbora djece odnose dominantno na:

- $\quad$ izbor centra interesa - između četiri, a najčešće dva ponuđena centra te

- tempo rada.

Izvan mogućnosti izbora djece jesu:

- $\quad$ teme za aktivnosti i učenje - odgojitelj bira teme aktivnosti

- materijali za aktivnosti - materijale je prethodno odabrao i pripremio odgojitelj

- $\quad$ način rada - visoka instruktivnost odgojitelja

- način izlaganja produkta aktivnosti

- $\quad$ vrijeme započinjanja i završetka aktivnosti

- $\quad$ način evaluacije.

Vidimo da se mogućnosti izbora djece odnose najviše na elemente organizacijske autonomije, a više razine autonomije, $\mathrm{u}$ obliku proceduralne ili kognitivne, potpuno izostaju (Stefanou i sur., 2004).

Konstatirali smo predominaciju prakse inzistiranja da 
DRUŠ. ISTRAŽ. ZAGREB GOD. 29 (2020), BR. 4, STR. 575-597

MAROJEVIĆ, J. I SUR.: "PEDAGOGIJA SLUŠANJA".. blju tranzicije između aktivnosti, dok ne završe zadatak, u pauzama, poslije jela, prije jela, dok jedan dio grupe izvodi neku aktivnost i slično - kao svojevrsnu "pedagogiju za stolom". Zaista, stol postaje ne samo simbol aktivnosti i učenja nego i simbol kontrole, ograničenja, odnosno simbol moći odgojitelja. U svjetlu rezultata istraživanja o indikatorima okruženja koji utječu na to shvaća li dijete neku aktivnost kao igru ili kao aktivnost formalnog učenja (što je prediktor uspješnosti u zadatku/aktivnosti), a među kojima dominira upravo mjesto izvođenja aktivnosti - pod ili stol (McInnes i sur., 2013) - zaključujemo da svojevrsna koncentriranost svih aktivnosti u vrtićkim grupama oko stola (strukturiranih ili slobodnih), a posebno prisilna koncentriranost, ometa razvoj osjećaja igranja, a samim tim i prakticiranje autonomije.

Mi smo se $u$ istraživanju poslužili tipologijom interaktivne moći, koju je razvio Carspecken (Carspecken, 1996). Kao što smo vidjeli, normativna moć naslonjena na manje ili više eksplicitno pozivanje na svoju "poziciju", koja se manifestira kroz visoku instruktivnost $\mathrm{u}$ aktivnostima, sumativnu evaluatorsku funkciju, zadržavanje materijala odnosno vremena početka rada materijalima i slično. Tu posebnu vrstu normativne moći nazvali smo epistemološka moć.

Posebno karakterističnim u domeni odnosa moći odgojitelj : dijete čini se to što nije zabilježen ni jedan slučaj inicijative djeteta u pogledu propitkivanja autoriteta odgojitelja, kao pokušaj prevrednovanja odnosa moći. To može značiti da su do predškolskog razdoblja te strategije "nepregovaranja", dominacije i utišavanja djetetova glasa već toliko razvijene, hijerarhijski odnosi moći već toliko čvrsto uspostavljeni da se više i ne postavlja pitanje mogućnosti stvaranja drukčije stvarnosti.

\section{ZAKLJUČAK}

Što, dakle, karakterizira odnos odgojitelja prema znanju i učenju $\mathrm{u}$ istraživanim vrtićkim sredinama, odnosno kakva je dominantna epistemologija odgojitelja? Nekoliko je zajedničkih ključnih odlika:

- $\quad$ važnim se pokazuje proces "obnavljanja" znanja

- $\quad$ proces "obnavljanja" znanja potpomognut je velikom dominacijom pitanja zatvorenoga tipa na temu/priču/pjesmu o kojoj je riječ dotičnoga dana

- $\quad$ u procesu učenja vrlo je važno da dijete "sluša" ono što odgojitelj govori - jer ako ne sluša, neće znati što i kako treba raditi

- $\quad$ za proces učenja vrlo su važne manipulativne aktivnosti djece

- $\quad$ vođene aktivnosti učenja najčešće podrazumijevaju i "proizvođenje" nečega

- $\quad$ proizvod, dječji uradak, ostavlja u sjeni sam proces učenja 
DRUŠ. ISTRAŽ. ZAGREB GOD. 29 (2020), BR. 4, STR. 575-597

MAROJEVIĆ, J. I SUR.: "PEDAGOGIJA SLUŠANJA"...
- $\quad$ s tim je u vezi i ideja o "dovršivosti" i konačnosti znanja

- "mjera" dovršivosti, odnosno konačnosti znanja, i njegov ključni evaluator jest odgojitelj

- mehanicistički, proizvodni jezik odgojitelja svjedoči o dekontekstualiziranosti i neživosti znanja

- $\quad$ ne prepoznaje se značenje unutarnje motivacije za učenje

- s obzirom na strukturu i tip zadataka i angažiranja djece, pokazuje se da odgojitelji nemaju posebnu vjeru u djetetove kompetencije, a ni u dijete kao "znanstvenika", mislioca (Slunjski, 2012).

Pogledamo li dominantne epistemološke postavke koje su se pojavile $u$ našem istraživanju, možemo bez sumnje tvrditi da počivaju na objektivističkom epistemološkom opredjeljenju odgojitelja (Hofer i Pintrich, 1997; Roth i Weinstock, 2013), koji znanje doživljavaju dominantno kroz autoritet njegova izvora (knjige, nastavnici, znanost), i to kao objektivnog i provjerljivog, danog uvijek $u$ jednoj znanstvenoj istini. Neka istraživanja uzroka kontrolirajućega motivacijskog stila u odnosu na onaj koji podržava autonomiju potvrdila su pretpostavku da odgojiteljeve implicitne pedagogije ili "teorije $\mathrm{u}$ akciji", odnosno osobne epistemologije, imaju važnu ulogu, pri čemu je podučavanje koje podržava autonomiju moguće predvidjeti relativističkom epistemološkom teorijom odgojitelja, a da je kontrolirajući motivacijski stil moguće predvidjeti objektivističkom (apsolutističkom) epistemološkom teorijom odgojitelja (Roth i Weinstock, 2013). Spomenuta dekontekstualizacija, utjelovljena između ostalog i u koncipiranju znanja i procesa učenja kao vrlo izoliranih, apstraktnih molekula ili čestica jedva povezivih s realnim životom i interesima djece, potvrda je žiruovskoga fenomena "objektifikacije" znanja (Žiru, 2011), te zaista i objektifikaciju i šablonizaciju procesa mišljenja i učenja same djece. Ovdje se prepoznaju svi oni "modeli socijalizacije" koji počivaju na autoritarnim odnosima u odgajanju - odsutnost istinskoga dijaloga između odgojitelja i djeteta, odsutnost djetetova izbora, (pre)ispitivanja ili istraživanja istine kao takve (Giroux, 1997). Sve prakse koje smo zapazili, a koje se tiču organizacije učenja, mogu se podvesti pod Kincheloev koncept FIDUROD epistemologije, $\mathrm{u}$ kojoj se na znanje gleda kao na formalno, nepromjenjivo, univerzalističko, redukcionističko, dekontekstualizirano i jednodimenzionalno (Kincheloe, 2008). U takvoj koncepciji učenja $u$ vrtiću djeca nemaju nikakvo autorstvo nad znanjem koje stječu - znanje kao takvo ostaje kao teorijski konstrukt prisutan "tamo negdje", bez pokušaja njegove primjene, dekomponiranja, istraživanja i slično. U najboljem slučaju, djeca su autori vlastitih uradaka, i to kao neka vrsta "iz- 
DRUŠ. ISTRAŽ. ZAGREB GOD. 29 (2020), BR. 4, STR. 575-597

MAROJEVIĆ, J. I SUR.: "PEDAGOGIJA SLUŠANJA"... rada, tj. "proizvođenja". Učenje kao stvaranje "radnih teorija" (Sands i sur., 2012) u neprekidnom procesu promjene, dopunjavanja i istraživanja stvarnosti i značenja koja joj se prepisuju posve izostaje.

Neke opće karakteristike odnosa moći u interakcijama odgojitelj : dijete, kroz prizmu mogućnosti djece za participaciju i uopće mogućnosti izbora jesu:

- Kad su u pitanju strukturirane aktivnosti djece, raspon njihove participacije $\mathrm{u}$ odlukama relativno je malen: mogu izabrati interesni centar $u$ kojem će izvoditi neku aktivnost te odlučivati o vremenu koje im je za to potrebno, o mjestu sjedenja i sl. - isključivo segmenti koji se tiču organizacijske autonomije.

- Proceduralna, a još manje kognitivna, autonomija djece $\mathrm{u}$ strukturiranim se zadacima gotovo nimalo ne potiče zbog visokoga stupnja instruktivnosti odgojitelja djeca ne biraju tijek aktivnosti, procedure, materijale, načine rada, načine vrednovanja, odnosno samovrednovanja, i sl.

- Zabrinjavajući je stupanj fizičke/tjelesne kontrole djece, bilo da je riječ o položaju tijela ili kretanju; svrha je takvih praksi kontrole uglavnom osiguravanje mira u odgojnoj grupi, kao neka vrsta strategije reguliranja ponašanja.

- Osim toga, pojava specifične "pedagogije za stolom" nije samo strategija reguliranja ponašanja nego i nedvosmislen pokazatelj "skolarizacije" odgojno-obrazovnog rada u vrtićima, gdje se od djece očekuje da "mirno sjede za stolom i rade dok ne završe zadatak", a i ponovno pokazatelj dominacije, odnosno (nad)moći, nad djetetom.

- Odnosi moći u interakciji odgojitelj : dijete manifestiraju se dominantno kroz normativnu moć odgojitelja i u njima se, implicitno ili eksplicitno, razlog nadređenog statusa odgojitelja uzima kao jedino utemeljenje mnogih odluka, $u$ obliku "jer ja tako kažem".

- Posebno ističemo svojevrsnu "epistemološku (nad)moć" utjelovljenu $\mathrm{u}$ visokoj instruktivnosti odgojitelja, predominaciji odgojiteljeva odlučivanja u situacijama strukturiranih aktivnosti, njihovu odnosu prema znanju i procesu spoznavanja, specifičnoj upotrebi pitanja i sl.

Kulturološki gledano, opći zaključak o dominantnom institucionalnom modelu djetinjstva kod nas $u$ velikoj je mjeri u skladu s rezultatima drugih istraživanja (Yudina, 2010; Reeve i sur., 2014; Koivula i sur., 2017) u regiji i u kulturama označenim kao "kolektivističke", kakva je i naša (Hofstede i sur., 2010), a prema kojima postoji objašnjavajuća veza između kolektivističke kulture i kontrolirajućega motivacijskog stila i autoritarnosti u odgajanju. Istraživanja Tomanovićeve $(2003,2004,2006)$ i Trebješanina (2008) pokazuju i dominaciju paternalizma kao dominantnog obrasca kolektivističkoga patrijarhalnog društva te općenito modela djetinjstva, koji Pešićeva naziva "defici- 
tarnim", i isto tako potvrđuje prevagu tradicionalne koncepcije odgojno-obrazovnih odnosa zasnovanih na (nad)moći odraslog (Colić, 1997; Turnšek, 2016; Slunjski, 2015).

\section{LITERATURA}

Aubrey, C., David, T., Godfrey, R. i Thompson, L. (2005). Early childhood educational research, issues in methodology and ethics. Routledge Falmer. https://doi.org/10.4324/9780203995877

Aronowitz, S. i Giroux, H. (1997). Postmodern education: Politics, culture and social criticism. University of Minnesota Press.

Berk, L. i Winsler, A. (1995). Scaffolding children's learning: Vygotsky and early childhood education. NAEYC.

Carspecken, P. (1996). Critical ethnography in educational research. Routledge.

Colić, V. (1997). Dečije jaslice gledane iz antropološkog ugla. Institut za pedagogiju i andragogiju.

Deci, E. i Ryan, R. (1995). Human autonomy - the basis for true self-esteem. U M. Kernis (Ur.), Efficacy, agency, and self-esteem (str. 31-48). Plenum Press. https://doi.org/10.1007/978-1-4899-1280-0_3

Deci, E., Schwartz, A., Sheinman, L. i Ryan, R. (1981). An instrument to assess adults' orientations toward control versus autonomy with children: Reflections on intrinsic motivation and perceived competence. Journal of Educational Psychology, 73(5), 642-650.

Dickinson, D. K. i Caswell, L. (2007). Building support for early literacy in pre-school classroom through in-service professional development: Effects of the Literacy Environment Enrichment Program (LEEP). Early Childhood Research Quarterly, 22(2), 243-260. https://doi.org/10.1016/ j.ecresq.2007.03.001

Erickson, F. i Wilson, J. (1982). Sights and sounds of life in schools: A resource guide to film and videotape for research and education. Michigan State University.

Erikson, E. (2008). Identitet $i$ životni ciklus. Zavod za udžbenike i nastavna sredstva.

Freeman, M. i Mathison, S. (2009). Researching children's experiences. The Guilford Press.

Freire, P. (1996). Pedagogy of oppressed. Penguin Books.

Freire, P. (2001). Pedagogy of freedom: Ethics, democracy, and civic courage. Rowman and Littlefield Publishers, Inc.

Freire, P. (2017). Pedagogija autonomije. Clio.

Giroux, H. (1997). Pedagogy and the politics of hope: Theory, culture and schooling. Westview Press.

Giroux, H. (1999). Border youth, difference, and postmodern education. U M. Castells, R. Flecha, P. Freire, H. Giroux, D. Macedo i P. Willis (Ur.), Critical education in the new information age (str. 93-117). Rowman and Littlefield Publishers, Inc.

Gjems, L. (2011). Why explanations matter: A study of co-construction of explanation between teachers and children in everyday conversation in kindergarten. European Early Childhood Education Research Journal, 19(4), 501-513. https://doi.org/10.1080/1350293X.2011.623537 
DRUŠ. ISTRAŽ. ZAGREB GOD. 29 (2020), BR. 4, STR. 575-597

MAROJEVIĆ, J. I SUR.: "PEDAGOGIJA SLUŠANJA"..
Goetz, J. P. i Lecompte, M. D. (1984). Ethnographic and qualitative design in educational research. Academic Press.

Goodwin, W. i Goodwin, L. (1996). Understanding quantitative and qualitative research in early childhood education. Teachers College Press.

Habermas, J. (1987). The theory of communicative action, Vol. 2, Lifeworld and system: A critique of functionalist reason. Beacon Press.

Hammersley, M. i Atkinson, P. (2007). Ethnography: Principles in practice (3rd ed.). Routledge. https://doi.org/10.4324/9780203944769

Hinchey, P. (2004). Becoming a critical educator: Defining a classroom identity, designing a critical pedagogy. Peter Lang.

Hofer, B. i Pintrich, P. (1997). The development of epistemological theories: Beliefes about knowledge and knowing and their relation to learning. Review od Educational Research, 67(1), 88-140. https://doi. org/10.3102/00346543067001088

Hofstede, G., Hofstede, G. J. i Minkov, M. (2010). Cultures and organizations: Software of the mind, intercultural cooperation and its importance for survival (3rd ed.). McGraw Hill.

Hymes, D. (2004). Ethnography, linguistics, narrative inequality. Taylor and Francis. https://doi.org/10.4324/9780203211816

Jang, H., Reeve, J. i Deci, E. (2010). Engaging students in learning activities: It is not autonomy support or structure but autonomy support and structure. Journal of Educational Psychology, 102(3), 588-600. https://doi.org/10.1037/a0019682

Jordan, B. (2004). Scaffolding learning and co-constructing understandings. U A. Anning, J. Cullen i M. Fleer (Ur.), Early childhood education, society and culture (str. 31-43). Sage Publications.

Kincheloe, J. (2008). Knowledge and critical pedagogy. An introduction. Springer. https://doi.org/10.1007/978-1-4020-8224-5

Koivula, I. M., Gregoriadis, A., Rautamies, E. i Grammatikopoulous, V. (2017). Finnish and Greek early childhood teachers' perspectives and practices in supporting children's autonomy. Early Childhood Development and Care, 189(6), 990-1003. https://doi.org/10.1080/03004430. 2017.1359583

Leibzig, J. i Leach, J. (2001). Praćenje i posmatranje dece. CIP.

Lincoln, Y. i Guba, E. (1985). Naturalistic inquiry. Sage Publications. https://doi.org/10.1016/0147-1767(85)90062-8

MacNaughton, G. (2000). Rethinking gender in early childhood education. Allen \& Unwin.

MacNaughton, G. (2003). Shaping early childhood: Learners, curriculum and context. Open University Press.

MacNaughton, G. (2004). Exploring critical constructivist perspectives on children's learning. U A. Anning, J. Cullen i M. Fleer (Ur.), Early childhood education, society and culture (str. 43-55). Sage Publications.

MacNaughton, G. (2005). Doing Foucault in early childhood education. Routledge. https://doi.org/10.4324/9780203465332

Malaguzzi, L. (1998). History, ideas and basic philosophy: An interview 
DRUŠ. ISTRAŽ. ZAGREB GOD. 29 (2020), BR. 4, STR. 575-597

MAROJEVIĆ, J. I SUR.: "PEDAGOGIJA SLUŠANJA"...
G. E. Forman (Ur.), The hundred languages of children, the reggio emilia approach - Advanced reflections (str. 49-99). Alex Publishing corporation. Marojević, J. i Milić, S. (2017). Habermas i Freire u dijalogu: pedagoško čitanje Habermasa. Croatian Journal of Education, 19(2), 605-635. https://doi.org/10.15516/cje.v19i2.2340

McInnes, K., Howard, J., Crowley, K. i Miles, G. (2013). The nature of adult-child interaction in the early years classroom: Implications for children's perceptions of play and subsequent learning behaviour. European Early Childhood Education Research Journal, 21(2), 268-282. https://doi.org/10.1080/1350293X.2013.789194

Meklaren, P. (2013). Život u školama. Eduka.

Murchison, J. (2010). Ethnography essentials: Designing, conducting and presenting your research. Jossey-Bass.

Parker, I. (1992). Discourse dynamics: Critical analysis for social and individual psychology. Routledge.

Peterson, S. i French, L. (2008). Supporting young's children explanations through inquiry science in preschool. Early Childhood Research Quarterly, 23(3), 395-408. https://doi.org/10.1016/j.ecresq.2008.01.003

Pole, C. i Morrison, M. (2003). Ethnography for education. Open University Press.

Prout, A. i James, A. (2005). A new paradigm for sociology of childhood? Provenance, promise and problems. U A. James i A. Prout (Ur.), Constructing and reconstructing childhood (str. 7-32). Falmer Press.

Reeve, J. (2016). Autonomy-supportive teaching: What is it, how to do it. U W. Liu, J. Chee Keng Wang i R. Ryan (Ur.), Building autonomous learners, perspectives from research and practice using self-determination theory (str. 129-153). Springer. https://doi.org/10.1007/978-981287-630-0_7

Reeve, J. i Jang, H. (2006). What teacher say and do to support students' autonomy during a learning activity. Journal of Educational Psychology, 98(1), 209-218. https://doi.org/10.1037/0022-0663.98.1.209

Reeve, J., Jang, H., Carrell, D., Jeon, S. i Barch, J. (2004). Enhancing students' engagement by increasing teachers' autonomy support. Motivation and Emotion, 28(2), 147-169. https://doi.org/10.1023/B:MOEM. $0000032312.95499 .6 \mathrm{f}$

Reeve, J., Vansteenkiste, M., Assor, A., Ahmad, I., Hyeon Cheon, S., Jand, H., Kaplan, H., Moss, J., Olaussen, B. i Wang, C. K. J. (2014). The beliefs that underline autonomy-supportive and controlling teaching: A multinational investigation. Motivation and Emotion, 38(1), 93-110. https://doi.org/10.1007/s11031-013-9367-0

Rinaldi, C. (2006). In dialogue with Reggio Emilia. Routledge.

Robinson, H. A. (1994). The ethnography of empowerment: The transformative power of classroom interaction. The Falmer Press.

Roth, G. i Weinstock, M. (2013). Teachers' epistemological beliefs as an antecedent of autonomy-supportive teaching. Motivation and Emotion, 37(3), 402-412. https://doi.org/10.1007/s11031-012-9338-x

Ryan, R. i Deci, E. (2000). Self-determination theory and the facilitation of intrinsic motivation, social development and well-being. American 
DRUŠ. ISTRAŽ. ZAGREB GOD. 29 (2020), BR. 4, STR. 575-597

MAROJEVIĆ, J. I SUR.: "PEDAGOGIJA SLUŠANJA"...
Ryan, R. M., Deci, E. L., Grolnick, W. S. i La Guardia, J. G. (2006). The significance of autonomy and autonomy support in psychological development and psychopathology. U D. Cicchetti i D. J. Cohen (Ur.), Developmental psychopathology: Theory and method (str. 795-849). John Wiley \& Sons, Inc.

Sands, L., Carr, M. i Lee, W. (2012). Question-asking and question-exploring. European Early Childhood Research Journal, 20(4), 553-564. https://doi.org/10.1080/1350293X.2012.737705

Schwandt, T. (2007). The SAGE dictionary of qualitative inquiry. Sage. https://doi.org/10.4135/9781412986281

Siraj-Blatchford, I. i Manni, L. (2008). 'Would you like to tidy up now?' An analysis of adult questioning in the English Foundation Stage. Early Years: An International Research Journal, 28(1), 5-22. https://doi.org/ 10.1080/09575140701842213

Siraj-Blatchford, I., Sylva, K., Muttock, S., Gilden, R. i Bell, D. (2002). Researching effective pedagogy in early years. Queen's Printer.

Shor, I. (1993). Education is politics. Paulo Freire's critical pedagogy. U P. McLaren i P. Leonard (Ur.), Paulo Freire: A critical encounter (str. 25-36). Routledge. https://doi.org/10.4324/9780203420263_chapter_2

Slunjski, E. (2012). Tragovima dječjih stopa. Profil International.

Slunjski, E. (2015). Izvan okvira. ELEMENT.

Stefanou, C., Perencevich, K., DiCintio, M. i Turner, J. (2004). Supporting autonomy in the Classroom: Ways teachers encourage student decision making and ownership. Educational Psychologist, 39(2), 97-100. https://doi.org/10.1207/s15326985ep3902_2

Tomanović, S. (2003). Negotiating children's participation and autonomy within families. International Journal of Children's Rights, 11(1), 51-71. https://doi.org/10.1163/092755603322384029

Tomanović, S. (2004). Family habitus as the cultural context for childhood. Childhood: A Global Journal Of Child Research, 11(3), 339-360. https://doi. org/10.1177/0907568204044887

Tomanović, S. (2006). Transition of young people in a transitional society: The case of Serbia. Journal of Youth Studies, 9(3), 269-285. https://doi. org/10.1080/13676260600805648

Trebješanin, Ž. (2008). Predstava o detetu u srpskoj kulturi. Sofos.

Turnšek, N. (2016). Theachers' implicit theories on child participation in preschool. Athens Journal of Education, 3(1), 7-18. https://doi.org/10. 30958/aje.3-1-1

Viling, K. (2016). Kvalitativna istraživanja u psihologiji. CLIO.

Vranješević, J. (2012). Razvojne kompetencije i participacija dece: od stvarnog ka mogućem. Učiteljski fakultet, Univerzitet u Beogradu.

Wiersma, W. (1991). Research methods in education. Allyn\&Bacon.

Yudina, E. (2010). The teacher's position in adult-child interaction in relation to a child's zone of proximal development. U A. Tuna i J. Hayden (Ur.), Early childhood programs ad the doorway to social cohesion: Application of Vygotsky's ideas from an East-West perspective (str. 45-63). 
DRUŠ. ISTRAŽ. ZAGREB GOD. 29 (2020), BR. 4, STR. 575-597

MAROJEVIĆ, J. I SUR.: "PEDAGOGIJA SLUŠANJA"...
Zlatev, J. (2008). The co-evolution of intersubjectivity and bodily mimesis. U J. Zlatev, T. P. Racine, C. Sinha i E. Itkonen (Ur.), The shared mind, perspectives on intersubjectivity (str. 215-244). John Benjamines Publishing Company. https://doi.org/10.1075/celcr.12.13zla

Zurek, A., Torquati, J. i Acar, I. (2014). Scaffolding as a tool for environmental education in early childhood. International Journal of Early Childhood Environmental Education, 2(1), 27-57.

Žiru, A. (2011). O kritičkoj pedagogiji. Eduka.

\section{"Pedagogy of Listening" vs. "Pedagogy of Listening to Educators": Ethnographic Research on Child Autonomy in Kindergartens in Montenegro}

Jovana MAROJEVIĆ, Katarina TODOROVIĆ, Saša MILIĆ

University of Montenegro, Faculty of Philosophy, Nikšić, Montenegro

The paper discusses the phenomenon of child autonomy from the perspective of educators' personal epistemologies and power relations in the adult-child interaction in the practices of institutional education in Montenegro. The construct of child autonomy is approached from the standpoint of critical-constructivist theory and the self-determination theory, as a socio-cultural product shaped by ethnopedagogies and personal epistemologies of educators. The main goal of the ethnographic study conducted in three preschool educational institutions in Montenegro was to explore the epistemological theories of educators through the analysis of institutional educational practices, given that "the ways of thinking about childhood fuse with institutionalized practices" (Prout \& James, 2005, p. 22). We conclude about the existence of an objectivist epistemological theory of educators and the dominance of normative power relations in educator-child interactions, and discuss a special type of epistemological "over-power". The comparability with the results of similar research in the region is stated, and it points to a possible explanatory connection between collectivist culture and the controlling motivational style and authoritarianism in education.

Keywords: educators' personal epistemologies, objectivist epistemology, power relations, preschool education

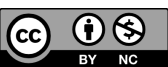

Međunarodna licenca / International License: Imenovanje-Nekomercijalno / Attribution-NonCommercial 